\title{
Characterization of the Ecosystem Services Rendered to the Population by Trees in the City of Parakou in Central Benin
}

\author{
Prucelle Elisee Zohoun ${ }^{1,}$, , David Makodjami Baloubi ${ }^{1}$, Emilia Mawugnon Azalou-Tingbe ${ }^{2}$, \\ Ibouraima Yabi ${ }^{1}$ \\ ${ }^{1}$ Institute of Geography and Land Planning, University of Abomey-Calavi, Abomey-Calavi, Benin \\ ${ }^{2}$ Department of Sociology-Anthropology, Faculty of Humanities and Social Sciences, University of Abomey-Calavi, Abomey-Calavi, Benin
}

Email address:

zohounprucelle@yahoo.fr (P. E. Zohoun),dbaloubi@yahoo.fr (D. M. Baloubi), emiliamawugnon@gmail.com (E. M. Azalou-Tingbe)

${ }^{*}$ Corresponding author

\section{To cite this article:}

Prucelle Elisee Zohoun, David Makodjami Baloubi, Emilia Mawugnon Azalou-Tingbe, Ibouraima Yabi. Characterization of the Ecosystem Services Rendered to the Population by Trees in the City of Parakou in Central Benin. Landscape Architecture and Regional Planning. Vol. 6, No. 1, 2021, pp. 8-18. doi: 10.11648/j.larp.20210601.12

Received: April 3, 2021; Accepted: April 24, 2021; Published: May 8, 2021

\begin{abstract}
The city of Parakou, like cities in developing countries, is experiencing rapid urbanization with the consequences of the destruction of the tree fabric and the progressive loss of cultural knowledge related to it. But in this city, tree species are spared or planted for several reasons. This paper aims to characterize the ecosystem services associated with these trees according to different social categories of urban dwellers. A sample of 370 inhabitants determined by Dagnelie's formula is used to collect the information. The rate of identification of the types of ecosystem services has been assessed. The analysis of covariance (ANCOVA) was used to analyze the influence of social groups on the rate of identification of services. The characterization of ecosystem services according to the different groups was done using the Correspondence Factor Analysis (CFA). A total of 30 ecosystem services grouped into 24 types in 4 categories, namely provisioning services, regulating services, cultural services and support services were identified. It emerges that the most cited services are respectively, in decreasing order, air regulation $(90 \%)$, food $(86 \%)$, aesthetic pleasure $(40 \%)$ and medicinal virtues $(36 \%)$. The socio-cultural group and the level of education strongly influence the rate of ecosystem identification. The characterization of ecosystem services by to social groups shows that the interest shown by each social group in ecosystem services depends on the benefits it derives from the tree on a daily basis. Although the population recognizes the services provided by trees, it is not actively involved in their conservation, which justifies the low density of the tree layer in the city of Parakou. This gives rise to research on the socio-economic and institutional constraints linked to the promotion of trees in the city of Parakou.
\end{abstract}

Keywords: City of Parakou, Trees, Ecosystem Services, Social Groups

\section{Introduction}

West African cities abound with a significant diversity of trees distributed in public gardens, private gardens, concessions, parks, plantations, roads, abandoned spaces, etc. [1-9] These plant formations are referred to in the literature as urban forests [10-12] or urban green spaces [13, 8]. Moreover, because of their ecological value, urban forests are often considered in the framework of sustainable development as a support for biodiversity [14]. In fact, urban forests constitute urban ecosystems $[15,16]$ and are the subject of an increasing number of studies, as the reasoned and optimised management of these ecosystems appears indispensable for the viability of societies [17]. These urban ecosystems constituted by the urban forest contribute to public health and increase the quality of life of city dwellers, for example by improving air quality and reducing noise [15]. They enrich the soil, slow down erosion due to runoff and provide shade. They also provide heat, food, light, health care, etc. [15]. In addition to these benefits of plants in cities, they strengthen social cohesion [18], thus making an important contribution to the livelihood and quality of life of 
urban residents [12]. This range of benefits that human populations derive, directly or indirectly, from ecosystem functions is called ecosystem services [19] and is divided into four categories: provisioning or harvesting services, regulating services, cultural services, and supporting or sustaining services [20].

However, urbanization, one of the main causes of land cover degradation $[21,12,22]$ disrupts the proper functioning of urban ecosystems through biodiversity loss and thus leads to a decline in ecosystem services [23]. In a context of strong urban expansion, ecosystem services in urban areas may have limitations and need to be further examined [24] and updated.

Indeed, the relationship between contemporary West African urban dwellers and the tree fabric is not well known, especially in this context of urbanization with ecological, economic and sociological impacts that are poorly known and difficult to assess [25]. According to Yengue [26], in the city as in the fields, the relationship between man and tree is complex, different according to place, species and ethnicity, and strongly changing over time.

From a simple caravanserai, the city of Parakou has become a flourishing center of regional exchange, now welcoming people of diverse origins, some of whom have settled there permanently. Its urban and peri-urban strip is strongly linked to transit, which has brought qualitative and quantitative changes in socio-cultural terms [27]. Indeed, in Parakou, $30.32 \%$ of the concessions are devoid of trees and there is a low density of the adult tree stratum, 18.85 trees/ha [28]. Thus, in a context of qualitative and quantitative sociocultural changes and low vegetation density, characterizing ecosystem services would allow a better understanding of the perception of different social groups of the tree and allow consideration of appropriate measures for the promotion and/or conservation of trees.

\section{Study Area}

A city of more than three centuries of existence [27], Parakou is located in central Benin between $9^{\circ} 13^{\prime}$ and $9^{\circ} 27^{\prime}$ north latitude and $2^{\circ} 25^{\prime}$ and $2^{\circ} 46^{\prime}$ east longitude. The local climate is Sudanian (humid tropical) characterized by the alternation of a rainy season from May to October and a dry season from November to April [29]. The dry season is marked by harmattan (a cold, dry wind). The vegetation is dominated by savannah with all its variants: wooded savannah, tree savannah, shrubby savannah. Vegetation in the concessions of the urban area has a high species richness with a high dominance of the Mangifera indica species [28]. The city covers an area of $441 \mathrm{~km}^{2}$ and comprises forty-two (42) urban districts (Figure 1) divided into three (03) borough with a population of 255,478 inhabitants. It has a density of 579 inhabitants $/ \mathrm{km}^{2}$ making it the most densely populated city in the Borgou county. Parakou is a cosmopolitan city whose main socio-cultural groups registered are as follows: Bariba and related (35\%), Fon and related (16.2\%), Yoruba and related $(15.5 \%)$, Dendi and related $(9.3 \%)$, Gua or Otamari and related $(6 \%)$ and Yoa and Lokpa and related (5.9\%), Peuhls (3.2\%), Adja and related (3.1\%) and others $(3.5 \%)$ [30].

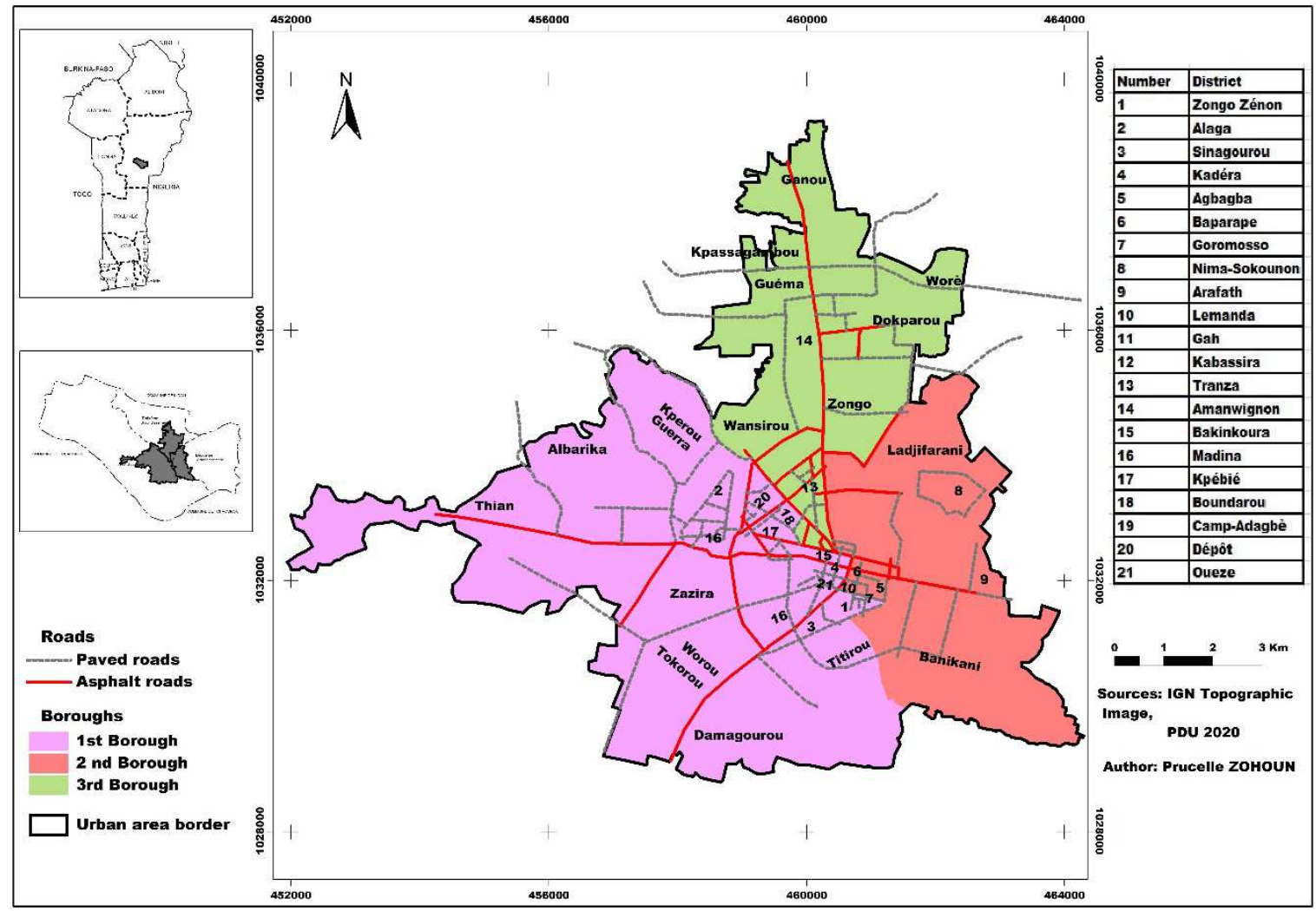

Figure 1. Location of the study zone and administration distribution. 


\section{Materials and Methods}

\subsection{Sampling and Data Collection}

A survey of 90 inhabitants, 30 per randomly selected borough as an exploratory phase, determined the proportion of people who recognize at least three (3) categories of ecosystem services as defined by [20]. This proportion was then used to determine the minimum sample size using Dagnelie's [31] formula:

$$
n=\frac{\cup_{1-\alpha / 2^{*}}^{2}(1-P)}{d^{2}}
$$

Where n: minimum sample size considered;

P: proportion of respondents who recognize at least three categories of tree ecosystem services, determined during the exploratory phase $(\mathrm{p}=0.4)$;

$\mathrm{U}_{1-\alpha / 2}=1.96$, the value of the normal random variable for a risk $\alpha=0.05$;

$\mathrm{d}$ : margin of error is $5 \%$.

The application of this formula gives $\mathrm{n}=368.79$ rounded to 370 inhabitants.

The choice of inhabitants was made randomly while covering the three districts of the city of Parakou. A structured questionnaire was used to fill in certain socioeconomic data such as gender, age, education level, socioprofessional activity, socio-cultural group and knowledge of ecosystem services. The socio-cultural groups were defined according to the classification of the National Institute of Statistics and Economic Analysis. Concerning ecosystem services, twenty-four (24) types grouped in four categories adapted to that of the Millennium Ecosystem Assessment [20] were used as a basis for the interview. They include six (6) provisioning services, ten (10) regulating services, five (05) cultural services and three (3) supporting services.

\subsection{Data Analysis}

A descriptive analysis of the information collected determined the socio-demographic profile of the respondents, the rate of identification and the importance value of the types and categories of ecosystem services.

The rate of identification of an ecosystem service or category of services is the percentage of respondents who recognize one of an ecosystem service. It is assessed by the value of importance (IV). It varies from 0 to 1 and is determined by the following formula [32]:

$$
\mathrm{IV}=\frac{\mathrm{n}_{\mathrm{i}} \mathrm{s}}{\mathrm{n}}
$$

Where $n_{\mathrm{i}} \mathrm{s}$ : number of respondents who consider a good to be an ecosystem service; $n$ : total number of respondents;

Values close to 0 indicate that very few respondents have a good knowledge of a type or category of ecosystem service. Values close to 1 , on the other hand, indicate that many respondents have a good knowledge of a type or category of ecosystem service.

The relationship between the number of services cited and the social groups, i.e. gender, age, education level, socioprofessional activity and socio-cultural group was assessed by an analysis of covariance (ANCOVA).

A Factor Correspondence Analysis (FCA) was conducted to characterize the services cited and the different social groups, including gender and age, level of education, socioprofessional activity and socio-cultural group. Statistical analyses were performed in R 3.5.0 software.

\section{Result}

\subsection{Respondent Structure}

Table 1 presents the socio-demographic profile of the respondents.

\begin{tabular}{|c|c|c|c|c|}
\hline Structure & Mean & Standard error & Min & Max \\
\hline Age of respondents & 34.95 & 12.89 & 17 & 80 \\
\hline Social group & Frequency & Percentage $(\%)$ & & \\
\hline \multicolumn{5}{|l|}{ Gender } \\
\hline Men & 200 & 54.05 & & \\
\hline Women & 170 & 45.95 & & \\
\hline Young men (17-49) & 163 & 44.05 & & \\
\hline Adult men (50 and over) & 36 & 9.72 & & \\
\hline Young women (17-49) & 158 & 42.73 & & \\
\hline Adult women ( 50 and over) & 11 & 2.98 & & \\
\hline \multicolumn{5}{|l|}{ Socio-cultural groups } \\
\hline Bariba and related & 94 & 2.41 & & \\
\hline Fon and related & 92 & 24.86 & & \\
\hline Dendi and related & 77 & 20.81 & & \\
\hline Yoruba and related & 54 & 14.59 & & \\
\hline Ditamari and related & 31 & 8.38 & & \\
\hline Lokpa and related & 12 & 3.24 & & \\
\hline Peulh & 7 & 1.89 & & \\
\hline Foreigner & 3 & 0.81 & & \\
\hline \multicolumn{5}{|l|}{ Educational level } \\
\hline High school & 152 & 41.08 & & \\
\hline Primary & 79 & 21.35 & & \\
\hline University & 76 & 20.54 & & \\
\hline Literate & 46 & 12.43 & & \\
\hline None & 17 & 4.59 & & \\
\hline \multicolumn{5}{|l|}{ Professional activities } \\
\hline Traders & 101 & 27.30 & & \\
\hline Salaried employee & 93 & 25.14 & & \\
\hline Artisans & 86 & 23.24 & & \\
\hline Students & 64 & 17.30 & & \\
\hline Housewife & 13 & 3.51 & & \\
\hline Farmers & 8 & 2.16 & & \\
\hline Breeder & 3 & 0.81 & & \\
\hline Others & 2 & 0.54 & & \\
\hline
\end{tabular}

Table 1. Socio-demographic profile of the respondents.

The analysis in Table 1 shows that the average age of respondents is about 35 with a minimum of 17 and a maximum of 80 . This implies the sense of responsibility of the people chosen. More than half of the sample has at least a secondary school education, which implies at least a relative understanding of the concept of ecosystem services. In addition, the main socio-cultural groups in the city were taken into account. Also, the presence of women in the survey demonstrates consideration of gender. Moreover, the sample takes into account all the socio-cultural segments of the city 
and makes it possible to collect representative information.

\subsection{Identification Rate of Ecosystem Service}

In the town of Parakou, some thirty ecosystem services are

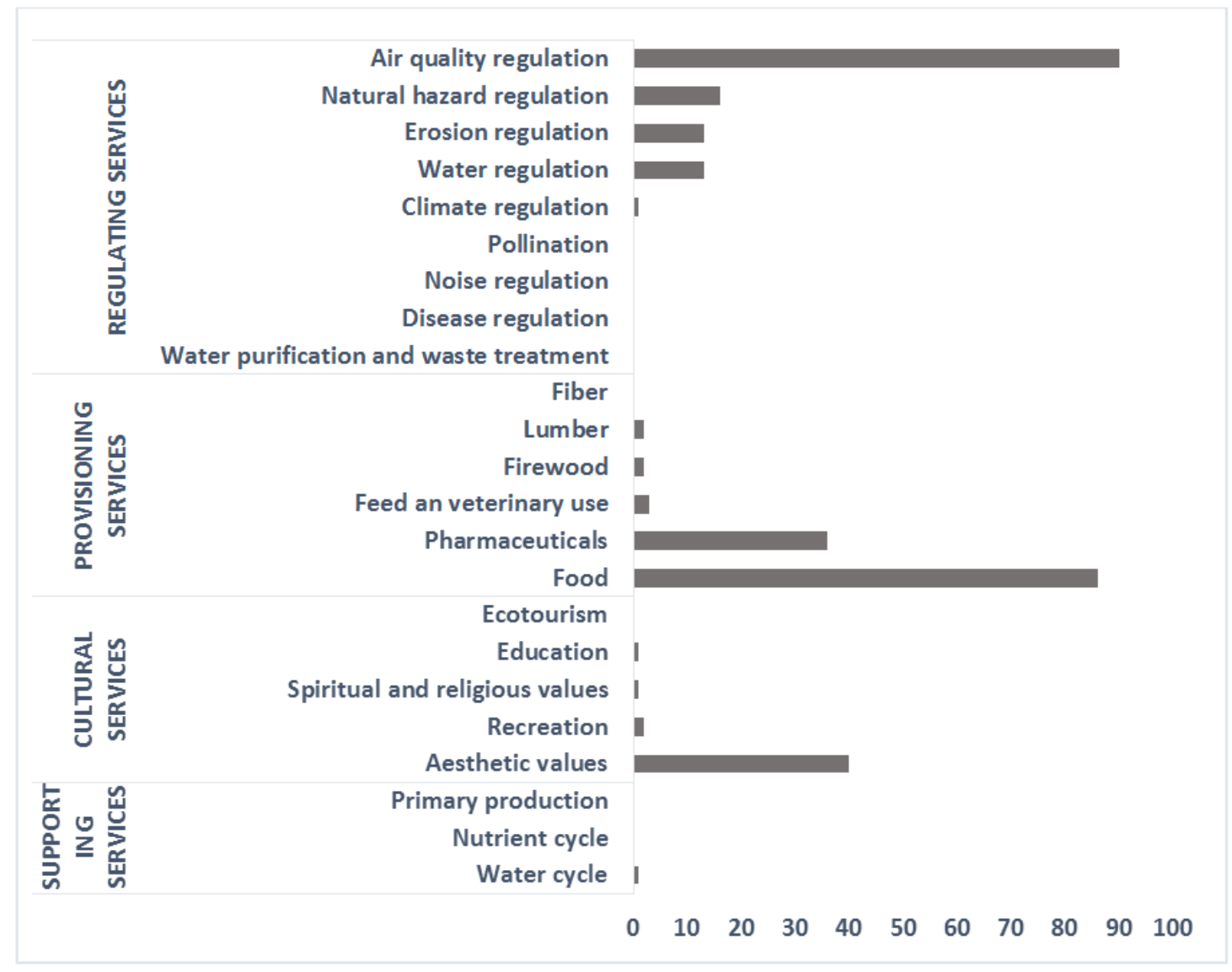

Figure 2. Identification rate of ecosystem services.

Figure 2 shows that the top five known urban tree services in the city of Parakou are, in order of importance, regulation of air quality $(90 \%)$, provision of food $(86 \%)$, aesthetic pleasure $(40 \%)$, medicinal virtues $(36 \%)$ and protection recognized by the population. These services are grouped into 24 types divided into the four different categories defined by [20] as shown in Figure 2.

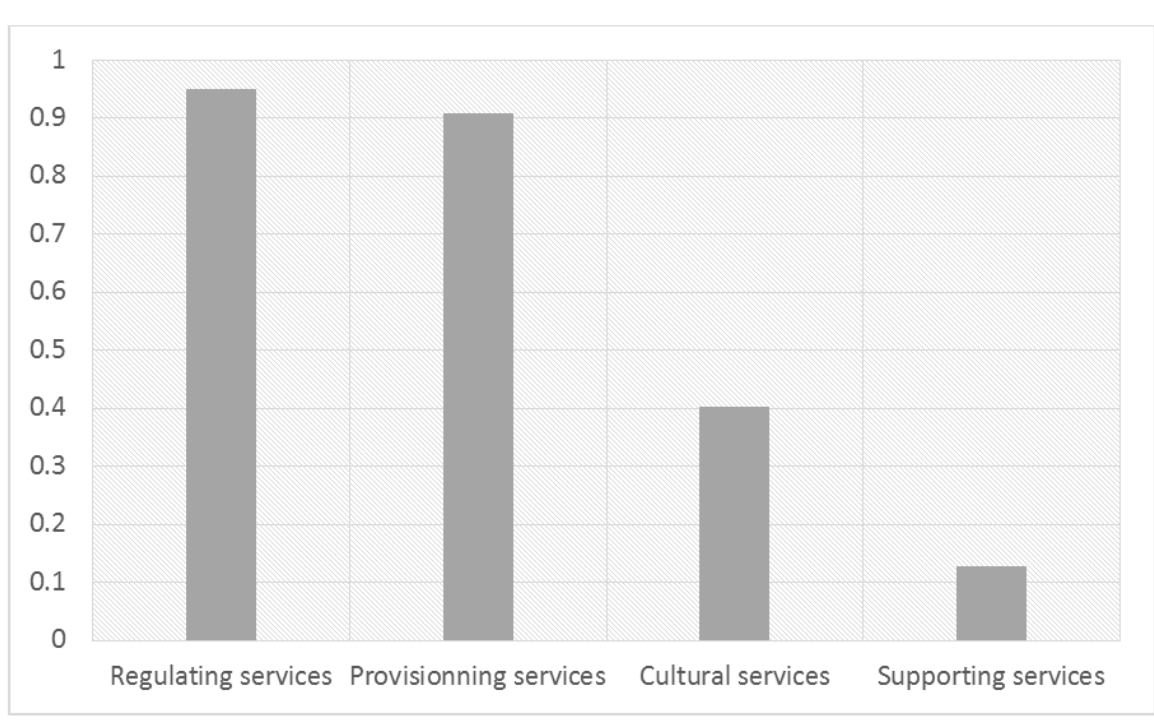

Figure 3. Importance value of ecosystem services categories. 


\subsection{Relationship Between the Rate of Identification of Ecosystem Services and Social Groups}

Covariance analysis shows that socio-cultural group (ANCOVA, $F=4.06, \mathrm{df}=8, P<0.001)$ and educational level $(F=$ $5.36, \mathrm{df}=4, P<0.001$ ) have a higly significant influence on the rate of identification of ecosystem services

\subsection{Characterization of Ecosystem Services by Social Group}

\subsubsection{Characterization of Ecosystem Services by Age and Gender}

The characterization of ecosystem services by age and gender was done by considering women and men between the ages of 17 and 49 years (Youth) and 50 years and over (Adults).

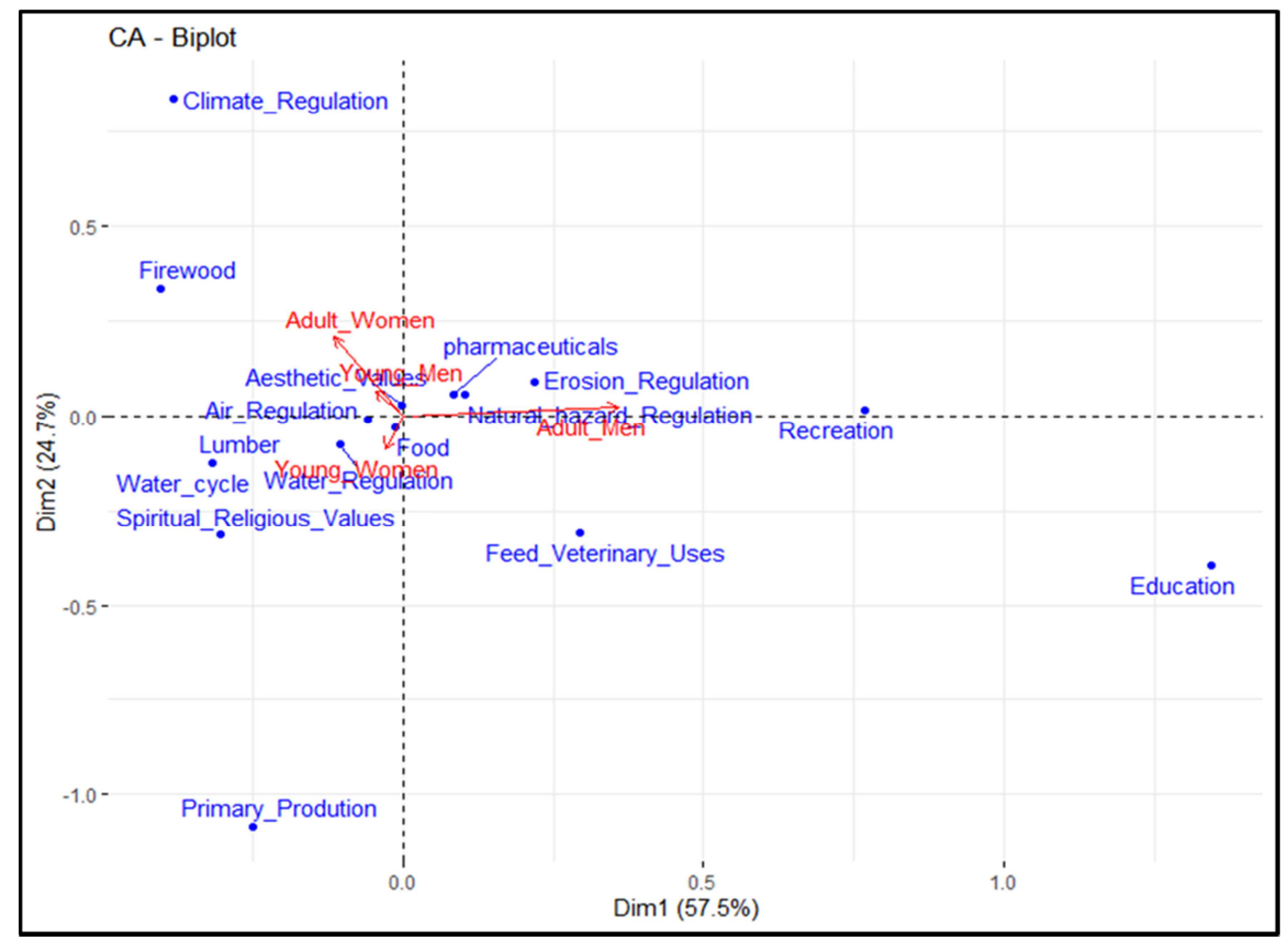

Figure 4. Ecosystem services by age and gender.

Analysis of the first two factor axes in Figure 4 shows $82.2 \%$ of the variance contained in the initial data. The projection of the sexes according to the age groups defined, on the plane formed by factor axes 1 and 2, shows that men aged 50 and over, i.e. adult men, identified more services such as the regulation of natural risks and soil erosion, medicinal virtues, and recreational activities. As for men in the 17 to 49 age group (youth), they were more interested in air regulation and the food provided by trees. In addition, women aged 50 and over (adults) are interested in air regulation and fuelwood supply. Women aged 17-49 (youth) were more interested in services such as food, water flow regulation, air regulation, timber and the water cycle. The aesthetic pleasure service is common to all age groups.

\subsubsection{Characterization of Ecosystem Services by Socio-professional Activities}

The characterization of ecosystem services by socio- professional groups is presented in figure 5 .

The analysis shows that the first two factor axes explain $67 \%$ of the variance contained in the data matrix analyzing the relationship between socio-professional groups and ecosystem services derived from trees in urban areas in the city of Parakou. The projection of the different groups on factorial axes 1 and 2 allows us to note that the majority of respondents in the Employees group identified the regulation of water flow, aesthetic pleasure, climate regulation.

On the other hand, the Learners, namely students and pupils, focused more on food, air regulation and firewood. As for the Shopkeepers, they were more interested in food. As for the Craftsmen, they chose fodder and veterinary use, regulation of natural risks, recreational activities and pedagogical education. The Housewives were interested in food and lumber while the Farmers were more interested in the regulation of erosion and medicinal virtues. 


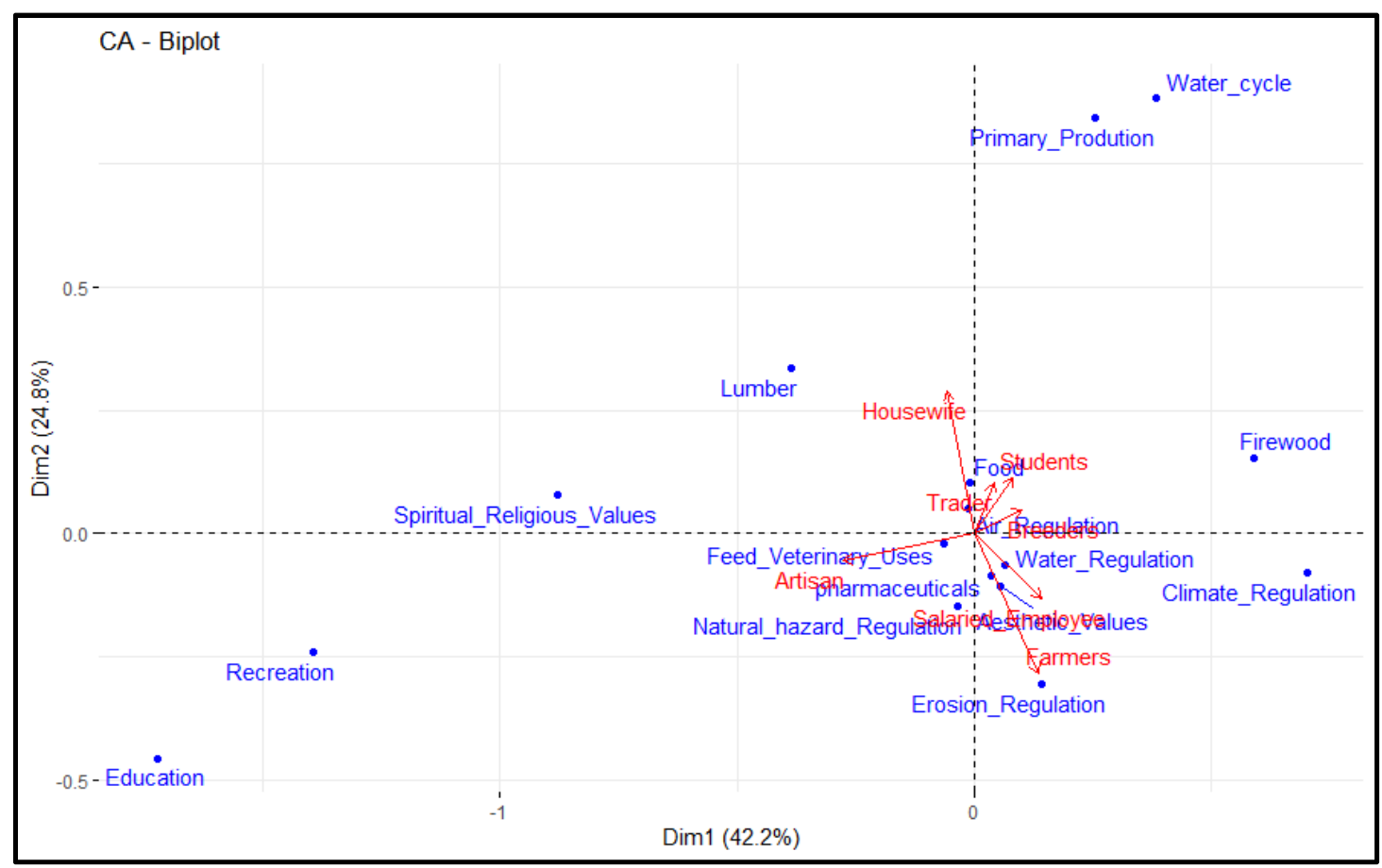

Figure 5. Ecosystem services by professional activities.

\subsubsection{Characterization of Ecosystem Services by Educational Level}

The characterization of ecosystem services according to the level of education of respondents is presented in Figure 6.

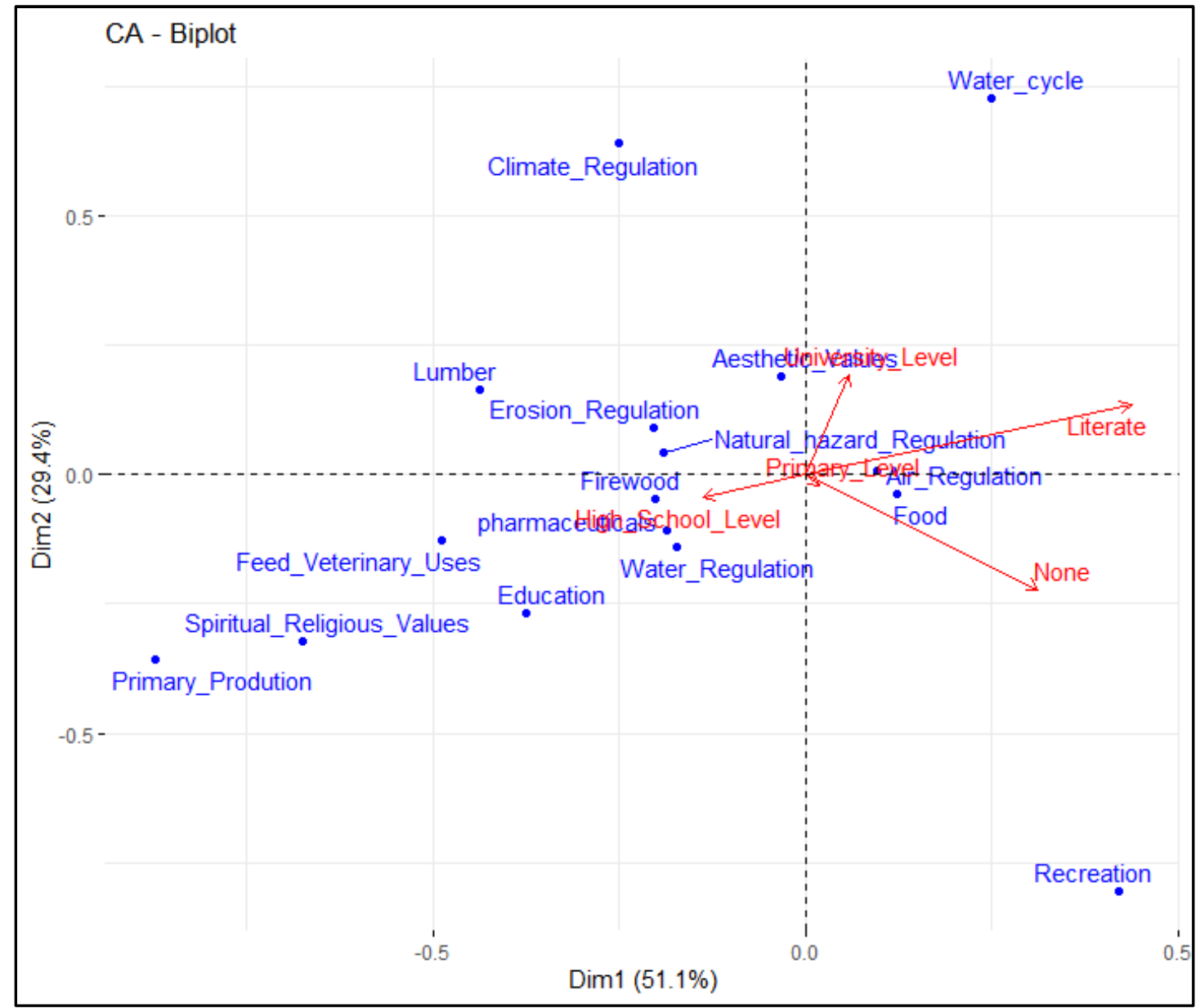

Figure 6. Ecosystem services by educational level. 
Taking into account the first two factor axes in Figure 6, 80.5 percent of the variation in the analysis of preference for services in the respondent tree by education level is evident. The positioning of the different groups on the factor axes reveals that those with No education identified types of services such as food and air regulation and recreation. The literate and respondents with a Primary education level made more choices on air regulation and food.

As for individuals with a Secondary level of education, they mostly identified medicinal virtues, regulation of water flow, regulation of natural hazards, fodder and veterinary use, firewood and pedagogical education, spiritual and religious values and primary production. On the other hand, respondents with a university level cited services such as air regulation and aesthetic pleasure.

\subsubsection{Characterization of Ecosystem Services by Socio-cultural Groups}

The characterization of ecosystem services according to socio-cultural groups in the city of Parakou is presented in Figure 7.

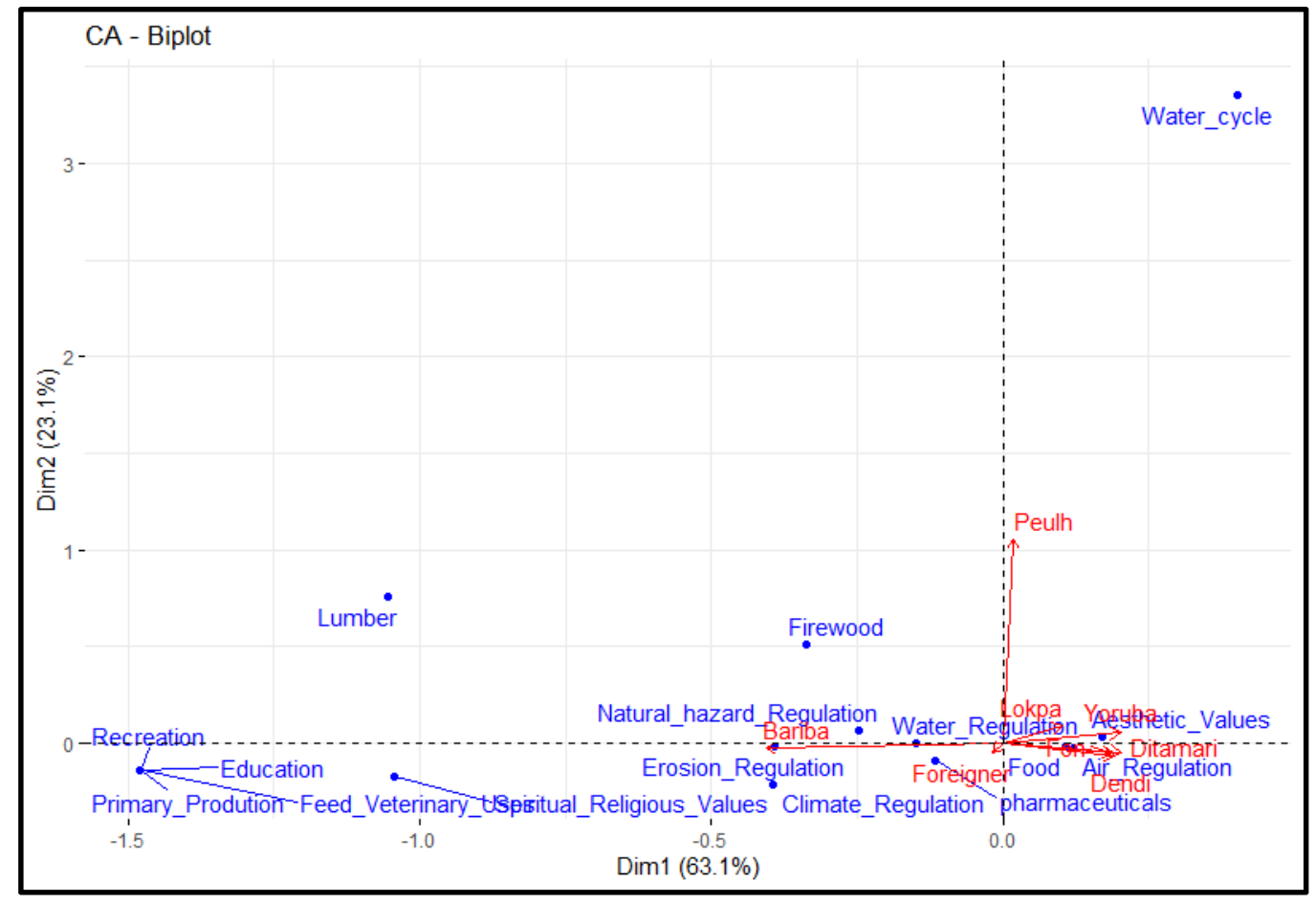

Figure 7. Ecosystem services by socio-cultural groups.

Analysis of the first two factor axes in Figure 7 shows $86.2 \%$ of the variance contained in the initial data. The projection of the socio-cultural groups on the plane formed by factor axes 1 and 2 allows us to note that the Bariba and related groups were interested in services such as food, regulation of water flows, regulation of natural risks, medicinal virtues, regulation of erosion, climate regulation, fodder and veterinary use, spiritual and religious values, recreation and education. The Fon and related, the Yoruba and related and the Ditamari identified in majority, the regulation of air, food and aesthetic pleasure. The interest of the Dendi and related and the Lokpa and related is focused on air regulation and food. In addition, the Peulh were interested in the water cycle (the theory that the tree brings rain) and the foreigners were more interested in medicinal virtues.

\section{Discussion}

\subsection{Identification of Types and Categories of Ecosystem Services in the City}

The present research has allowed to assess the knowledge of the inhabitants of Parakou on the ecosystem services rendered by the urban forest. It also allowed to identify the social factors that influence this knowledge and to analyze the trend of the different social groups in the city towards the ecosystem services rendered by trees in urban areas. The results show that the urban dwellers of the city of Parakou have diverse knowledge and interests in the benefits of trees. In fact, about thirty goods and services grouped into 24 types were cited by respondents. These different types can be found in the four categories of services defined by [20], namely supply services, regulatory services, non-material cultural services and support services. Considering the categories, regulatory services are the most cited and occupy the first position with an importance value of 0.95 . Next comes the supply services with an importance value of 0.90 . These values close to 1 indicate that the majority of respondents have a good knowledge of these services. On the other hand, cultural services and support services have proportions of 0.40 and 0.13 respectively. These values are close to 0 and thus indicate that only a minority of city 
dwellers have a good knowledge of these two categories of ecosystem services. These results confirm those of some authors that, unlike rural communities that prioritize substantial ecosystem benefits [33], the urban community values abstract services [34].

Moreover, in the category of regulating services, air regulation occupies the first place, followed by the regulation of natural risks (storm, flooding, etc.), the regulation of erosion and the regulation of water flows (rainwater drainage, drying up of wells, etc.).

Indeed, the results of [35] indicate that the community in the Sudano-Guinean zone of Benin is mainly aware of regulatory services, namely those related to air quality and natural hazard regulation. Similarly, [36] showed that in the urban area of the city of N'djamena, $98.6 \%$ of the population planted trees for shade and coolness. To explain this fact, it is possible to highlight the influence of the urban heat island especially in tropical cities. For example, in northern Cameroon as in Burkina Faso, the difference in appearance between urban areas and uninhabited places is very striking. Cities spread out under tall trees, giving them the appearance of oases in the middle of the desert, especially in the dry season [26].

Similarly, according to [25], in Ouagadougou, tree is subject to various uses related to daily life. However, the shade it provides is the first advantage appreciated by the population: the courtyard being the main place of life of every city dweller, the presence of a shady spot is therefore essential. Moreover, knowledge of the tree's role in regulating the climate (local, regional and global) remains very low among the population. This shows the need to sensitize the different actors on the phenomenon of climate change and the role of the tree in terms of mitigation and adaptation.

In the category of supporting services, food provision comes first. After food service comes medicinal use, fodder collection and veterinary use for the animals, and the collection of firewood and timber. The results obtained in this category are similar to those obtained by [37] who showed that human food is the first collection service provided by the timber stand. Indeed, fruit production is one of the important attractions of the yard tree. As such, Mangifera indica is unanimously accepted both in the town of Parakou and in several West African cities [25, 6, 8, 28].

In the cultural services category, aesthetic pleasure had a higher frequency of citation. Next in order of importance came recreational recreation, spiritual and religious values, and educational education, respectively. In the city, trees contribute to the beautification of a property or public space. They are used as a design element by playing with their shapes, heights and colors. This is the example of green spaces and line trees. In private concessions, trees are used as screens to preserve privacy. Some trees commonly known as false Ashoka tree (Polyalthia longifolia) and logwood (Haematoxylum campechianum) are used to modulate the viewpoint of an observer, in particular by influencing the perception of the size of a house or by allowing certain elements of a view to be hidden. Trees can also be used to ensure the privacy of a property through screens, hedges or wooded areas.

For the support services category, only the water cycle service was cited, as water is life. This can be explained by the fact that support services are not tangible and do not have a direct effect on the population.

The diversity of ecosystem services cited by the populations of Parakou can be explained by the rich specific diversity that the city abounds in [28] favoured by the diversity of socio-cultural groups each holding ethnobotanical knowledge for each woody species. Indeed, species such as Mangifera indica, Carica papaya, Moringa oleifera, Ficus polita, Azadirachta indica, Polyalthia longifolia, Calotropis procera, Cocos nucifera, Citrus sinensis, Psidium guayava are the ten most frequent species in the concessions of the city of Parakou [28]. Most of these species have several uses, namely, food, medicinal, windbreaks, fodder and veterinary use for pets, beautification and others.

\subsection{Correlation Between the Rate of Identification of Ecosystem Services and Social Groups}

The analysis of the covariance between the rate of identification of ecosystem services and social groups, namely gender, age, education, socio-professional activity and socio-cultural group was evaluated, revealing that education level and socio-cultural group are determining factors in the knowledge of ecosystem services. Indeed, the analysis of Figure 7 shows that respondents with a high school level of education identified more ecosystem services than the other groups. This knowledge could be due to several tree-related themes addressed during the school curriculum. At the level of socio-cultural groups, the analysis in Figure 7 shows that Bariba and related people cited more services than the remaining groups. This shows a strong attachment of this group to the tree and prompts studies to explain this phenomenon.

\subsection{Characterization of Ecosystem Services by Social Groups}

The characterization of ecosystem services by education level found that those with No education identified types of services such as food and air regulation and recreation. Literacy and Primary education respondents were more likely to identify air regulation and food. As for individuals with a Secondary level of education, they mostly identified the regulation of natural risks, medicinal virtues, regulation of water flow, firewood, fodder and veterinary use, pedagogical education and spiritual and religious values and primary production. On the other hand, respondents with a university degree cited services such as air regulation and aesthetic pleasure. These results show that the higher the level of education, the better the perception of ecosystem services. The level of instruction or education could induce people's attitude to support conservation policies and improve attitudes towards natural resources [38, 39, 40, 41] cited by [35]. The characterization of ecosystem services according to socio-cultural groups in the city of Parakou revealed that 
Bariba and related people have a good knowledge of the provisioning, regulating and cultural services of the tree. In Parakou, it is mainly Bariba women who sell firewood commonly known as "Dan gui". They also sell herbal tea leaves that treat many illnesses. In addition, [42] found that Bariba, also known as Baatombou, are more interested in educational services, services related to land. Thus, there are many traditional healers in this socio-cultural group, hence the high frequency of citation of medicinal virtues and spiritual values in this group. They are also goat breeders and are interested in fodder and the veterinary use of plants. All this explains the choice of different ecosystem services by this socio-cultural group.

As for Fon and related, Yoruba and related, the trend is towards air regulation, food and aesthetic pleasure. The Fon and Yoruba are the dominant peoples respectively of South and Central Benin where the vegetation is more diversified and denser. This biogeographical reality may favour the multiple uses of woody species for various purposes. The interest of the Dendi and related and the Lokpa and related to regulate air and food could be explained by the floristic diversity of the Sudano-Guinean zone to which the origin of these peoples belongs. The Peulhs for their part were more interested in the water cycle. Indeed, this nomadic and herding people is in perpetual search of pastures and water points for livestock.

\section{Conclusion}

This study found that the goods and services provided by trees are well known and valued in urban areas. However, the best-known services are regulatory services, supply services and non-material cultural services. Support services are little known. On the other hand, in the regulation services category, the air regulation service is more appreciated. In the category of supply services, it is the food, namely the collection of fruits and leafy vegetables. In the category of non-material cultural services, it is the aesthetic pleasure derived from trees.

In addition, the distribution of ecosystem services at the level of social groups reveals the level of education and sociocultural group have an impact on the level of knowledge of ecosystem services. The characterization of ecosystem services according to social groups shows that the identification of a service is related to the socio-economic benefits directly derived from the tree in the daily life of each social group. In spite of the numerous benefits of the tree known by the population, the observation of the state of the art shows a regression of tree cover in both private and public domains. Trees certainly bring a range of benefits in urban areas but they could bring even more if they are integrated into urban planning with the involvement of the population, in this case the socio-cultural groups. However, an analysis study of the socio-economic and institutional constraints related to the promotion of trees in urban areas is necessary in the cities of Benin in general and that of Parakou in particular.

\section{Acknowledgements}

The authors express their thanks to the Scientific Council of the University of Abomey-Calavi which financed this research trough the program "Competitive Research Fund, phase III." They are grateful to the reviewers who, through their observations and suggestions, have helped improve the quality of the article.

\section{References}

[1] Lougbegnon, T. O. (2013). Evaluation of the diversity of urban forest species in the city of Porto-Novo and their use by local populations. «Revue de géographie du laboratoire Leïdi» 11, 326-341.

[2] Osseni, A. A., Tohozin, C. A. B., Mouhamadou, I. T. \& Sinsin, A. B. (2014). Contribution of GIS in the floristic analysis of green spaces in the city of Porto-Novo in Benin. «Rev. Ivoir. Sci. Technol». 23, 103-121.

[3] Vroh, B. T. A., Tiebre, M. S. \& N'guessan, K. E. (2014). Urban plant diversity and carbon stock estimation: the case of the Plateeau commune, Abidjan, Ivory Coast. «Afrique Science». 10 (3) 329- 340.

[4] Kouadio, Y. J. C., Vroh, B. T. A., Gone Bi, Z. B., Adou Yao, C. Y. \& N'Guessan, K. E. (2016). Evaluation of the diversity and estimation of the biomass of the trees of alignment of the communes of Plateau and Cocody (Abidjan-Ivory Coast). «Journal of Applied Biosciences ». 97, 9141-9151. doi: 10.4314/jab.v97i1.1.

[5] Agbelade, A. D., Onyekwelu, J. C. \& Oyun, M. B. (2017). Tree Species Richness, Diversity, and Vegetation Index for Federal Capital Territory, Abuja, Nigeria. International Journal of Forestry Research. 2017, 1-12. doi: $10.1155 / 2017 / 4549756$.

[6] Folega, F., Kanda, M., Konate, D., Pereki, H., Wala, K., Atakpama W., Akuete, A. F., \& Akpagana, K. (2017). Urban forestry and atmospheric carbon sequestration potential in the urban and peri-urban area of Kpalimé (Togo). «Rev. Sc. Env. Univ., Lomé (Togo)». 1 (14), 1812-1403.

[7] Amontcha, A. M., Djego, J. G., Toko Imorou, I. \& Sinsin, B. A. (2017). Phytodiversity and uses of private green spaces in the cities of Greater Nokoué (South-Benin). «J. Rech. Sci. Univ. Lomé (Togo) », 17 (2), 117-140.

[8] Nero, B. F., Callo-Concha, D. \& Denich, M. (2018). Structure, Diversity, and Carbon Stocks of the Tree Community of Kumasi, Ghana. Forests. 9 (519), 1-17. doi: $10.3390 /$ f 9090519 .

[9] Moussa, S., Kuyah, S., Kyereh, B., Tougiani, A. \& Mahamane, S. (2020). Diversity and structure of urban forests of Sahel cities in Niger. Urban Ecosystems. 23, 851-864. doi: 10.1007/s1 1252-020-00984-6.

[10] Nowak, D. J., Crane, E. D., Stevens, J. C., Hoehn, R. E., Walton, J. T. \& Bond, J. (2008). A Ground-Based Method of Assessing Urban Forest Structure and Ecosystem Services. Arboriculture \& Urban Forestry. 34 (6), 347-358.

[11] Selmi, W. (2014). Ecosystem services provided by urban vegetation, application of evaluation approaches to the city of Strasbourg. Geography. "Université de Strasbourg, 2014. Français. tel01136771v3 ». 
[12] Salbitano F., Borelli S., Conigliaro, M., Chen Y. (2017). Urban and Peri-urban forestry guidelines. FAO Studies: Forest 178 (2017). Rome, FAO.

[13] Hillsdon, M., Panter, J., Foster, C., Jones A. (2006). The relationship between access and quality of urban green space with population physical activity. Public health. 120 (12), $1127-1132$

[14] Mehdi, L., Weber, C., Di Pietro \& F., SELMI, W. (2012). Evolution of the place of vegetation in the city, from green space to green grid. " [VertigO] La revue électronique en sciences de l'environnement, 12 (2)».

[15] Bolund, P. \& Hunhammar, S. (1999). Ecosystem services in urban areas. Ecological economics. 29, 293-301.

[16] Selmi, W., Weber, C. \& Mehdi L. (2013). Multifunctionality of urban green spaces. " [VertigO] La revue électronique en sciences de l'environnement, 13 (2) (2013)».

[17] Gomez-baggethun, E., \& Barton D. N. (2013) «Classifying and valuing ecosystem services for urban planning ». Ecological Economics. 86, 235-245.

[18] Arnberger, A. \& Eder, R. (2012). The influence of green space on community attachment of urban and suburban residents. Urban forestry \&Urban Greening. 11 (1), 41-49.

[19] Costanza, R., D’Arge, R., De groot, R., Farberk, S., Grasso, M., Hannon B., Limburg K., Naeem, S., O'neill, R. V., Paruelo, J., Raskin, R. G., Suttonkk, P. \& Belt M. V. D. (1997). The value of the world's ecosystem services and natural capital, Nature. 387, 253-260.

[20] Millenium Ecosystem Assessment (2005) Ecosystems and human well-being, [En ligne] URL: http://www.maweb.org/documents/document 356.aspx.pdf

[21] Hountondji, Y. H. (2008). Environmental dynamics in the Sahelian and Sudanian zones of West Africa: Analysis of changes and assessment of land cover degradation. «Thèse de doctorat; Université de Liège. pp153 ».

[22] Biga, I., Amani, A., Soumana, I., Bachir, M. \& Mahamane, A. (2020). Spatio-temporal dynamics of land use in the communes of Torodi, Gothèye et Tagazar in the Tillabéry region of Niger. «Int. J. Biol. Chem. Sci ». 14(3), 949-965. DOI: https://doi.org/10.4314/ijbcs.v14i3.24.

[23] Kaboré S. A., Schumann, K., Hien, M., Lykke A. M, Hahn, K. $\&$ Nacro, H. B. (2015).Adaptation strategy to the reduction of ecosystem services: the case of the substitution potential of three forest species in southwest of Burkina Faso. «Int. J. Biol. Chem.Sci».9(3),1194-1208.DOI:

http://dx.doi.org/10.4314/ijbcs.v9i3.5.

[24] SIEBER, J., Fremgen L., PONS, M. (2015). Assessment of Ecosystem Services for Urban Resilience - Case Study in Singapore. GRF Davos Planet@Risk, Special Issue on the 5th IDRC Davos 3(1) (2014): 77-86.

[25] Besse, F., Dutreve, B. \& Pinatel, M. (2019). The place of the tree in two West African capitals: Nouakchott and Ouagadougou "Actes de l'atelier Cirad-Coraf, 20-24 avril 1998, Montpellier, France».

[26] YENGUE J. L. (2017). Radioscopie of territories in Africa through the tree (Cameroun et Burkina Faso), landscape projects [one line], $16 \mid 2017$, put on line on 12 juillet 2017, consulted on 30 avril 2020. URL:
http://journals.openedition.org/paysage/6147;DOI: https://doi.org/10.4000/paysage.6147

[27] Aboudou, Y. M. A. R. (2010). Dynamics of urban peripheries in Parakou: manifestations and socio-economic and environmental impacts. « Thèse de Doctorat Unique (Nouveau Régime): Option Gestion de l'Environnement, Spécialité Dynamique des Ecosystèmes et Aménagement du territoire, Ecole Doctorale Pluridisciplinaire "Espaces, Cultures et Développement ". UAC, $315 \mathrm{p}$ ».

[28] Zohoun, P. E., Djaouga, M., Zakari, S., Baloubi, D. M. \& Yabi I. (2020). Diversity, tree structure and description of afforestation in the urban concessions of Parakou in central Benin. «Journal of Applied Biosciences» 154, 15842 - 15852 https://doi.org/10.35759/JABs.154.1.

[29] Yolou, F. I., Yabi, I., Kombieni, F. Tovihoudji, PG, Yabi, J. A (2015). Market gardening in urban areas of Parakou in North Benin and its economic profitability. «Int. J. Innovation Sci. Res». 19 (2), 290-302.

[30] National Institute of Statistic and Economic Analysis (2015). RGPH4: What to retain from the population in 2013? Service of Demographic studies, Cotonou, Benin.

[31] Dagnelie, P. (1998). Theoretical and applied statistics. De Boeck et Larcier, Belgique 2

[32] Byg, A. \& Balslev H. (2001). Diversity and use of palms in Zahamena, eastern Madagascar. Biodiversity and Conservation 10, 951-970.

[33] Martin-lopez, B., Iniesta-Arandia, I., Garcia-Llorente, M., Palomo, I., Casado-Arzuaga, I., Amo D., Gomezbaggethun, E., Oterosrozas, E., Palacios-Agundez, I., Willaarts B., Gonzalez, J., Santos-Martin, F., Onaindia, M., Lopez-santiago, C. \& Montes, C. (2012). Uncovering ecosystem service bundles through social preferences. PLoS One, 7, 2012. https://doi.org/10.1371/journal.pone.003 8970.

[34] Kroll, F., Müller, F., Haase, D. \& FOHRER, N. (2012). Rural-urban gradient analysis of ecosystem services supply and demand dynamics. Land Use Policy. 29, 521-535. DOI: https://doi.org/10.1016/j.landusepol.2011.07.008

[35] Ahononga, F. C., Gouwakinnou, G. N., Biaou, S. S. H., Biaou, S. \& Sonounameto, R. C. (2020). Socioeconomic factors determining ecosystem services local perceptions in two ecological zones in Benin (West Africa). Int. J. Biol. Chem. Sci. 14 (5), 1716-1733

[36] FAO (2012). Support to formulation of a strategy and an action plan for urban and peri-urban forestry in N'Djamena. Role and place of trees in urban and peri-urban areas «Document de travail sur la foresterie urbaine et périurbaine 6 (2012) 95 p. Rome».

[37] Ngom, D., Charahabil, M. M., Sarr, O., Bakhoum, A. \& Akpo, L. E. (2005). Community perceptions of the provisioning ecosystem services provided by the woody stant in the Ferlo Biosphere Reserve (Sénégal). «VertigO». 14 (2), 2014.

[38] Mensah, S., Veldtman, R., Assogbadjo, A. E., Ham, C., Glèlè Kakaï, R. \& Seifert, T. (2017). Ecosystem service importance and use vary with socio-environmental factors: A study from household-surveys in local communities of South Africa. Ecosystem Services. 23, 1-8. DOI: https://doi.org/10.1016/j.ecoser.2016.10. 018 
[39] Ahammad, R., Stacey, N. \& Sunderland T. C. H. (2019). Use and perceived importance of forest ecosystem services in rural livelihoods of Chittagong Hill Tracts, Bangladesh. Ecosystem Services. $\quad 35, \quad 87-98 . \quad$ DOI: https://doi.org/10.1016/j.ecoser.2018.11. 009.

[40] Gouwakinnou, G. N., Biaou, S., Vodouhe, F. G., Tovihessi M. S., Awessou B. K. \& Biaou, H. S. S. (2019). Local perceptions and factors determining ecosystem services identification around two forest reserves in Northern Benin. Journal of Ethnobiology and Ethnomedicine. 61, 1-12. DOI: https://doi.org/10.1186/s13002019-0343-y.
[41] Moutouama, F. T., Biaou, S. S. H., Kyereh. B., Asante, W. A. \& Natta, A. K. (2019). Factors shaping local people's perception of ecosystem services in the Atacora Chain of Mountains, a biodiversity hotspot in northern Benin. Journal of Ethnobiology and Ethnomedicine. 15, 1-10. DOI: https://doi.org/10.1186/s13002-0190317-0.

[42] Sabi Lolo Ilou, B., Toko Imorou, I., Vigninou, T. \& Thoma, O. (2019). Characterization of Ecosystem Services in the Transboundary Biosphere Reserve of $\mathrm{W}$ in North Benin. European Scientific Journal. 15 (36), 278-295. Doi:10.19044/esj.2019.v15n36p278. 